\title{
胆汁酸ミセル動電クロマトグラフィーによる アミノ酸光学異性体分離機構の統計的解析
}

\author{
池永 裕 ${ }^{\mathrm{a}} 、$ 花木 美紗 ${ }^{\mathrm{a}}$ 、隅本 倫徳、椎木 弘 ${ }^{\mathrm{b}}$ 、長岡 勉 ${ }^{\mathrm{b}}$ 、 \\ 堀 憲次 ${ }^{\mathrm{a}^{*}}$

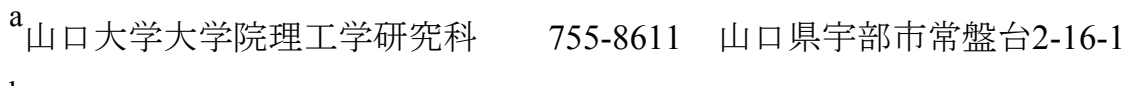

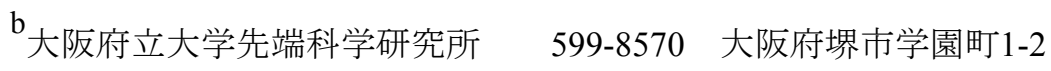

(Received April 6, 2007; Accepted May 28, 2007)

\begin{abstract}
キャピラリー電気泳動(Capillary Electrophoresis、CE)の分離モードの一つであるミセル動電ク ロマトグラフィー(Micellar Electrokinetic Chromatography、MEKC)は有機化合物の光学異性体分離 を行うことが可能である。その分離機構には泳動液中のミセルと測定試料の疎水的相互作用の 違いが関与していると考えられている。しかしながら、分離機構に関与しているパラメータを 統計的手法を用いて解析し、分離に重要なパラメータを特定することは、これまで行われてい ない。本研究では、界面活性剤として4種類の胆汁酸類、コール酸(CA)、タウロコール酸(TCA)、 ケノデオキシコール酸(CDCA)、デオキシコール酸(DCA)を用いて、MEKCによる11種類のアミ ノ酸の光学異性体分離を行い、得られた結果から分離度(Rs)を算出した。全ての胆汁酸類におい て、アミノ酸の物性值や実験条件などの6種類の值を説明変数とし、算出したRsを目的変数とす るGA-PLS解析を行い、Rsに影響を与えるパラメータについて検討を行った。その結果、予想通 り全ての系においてアミノ酸の疎水性度 $(\mathrm{Hi})$ が選択された。この結果は、疎水的相互作用が関与 していることが統計的に証明されたことを示している。しかしながら、CDCA、DCAを用いた実 験結果は、6変数から選択された 4 または3変数を用いることでモデル化可能であったが、CA、 TCAにおいてはそれらのRsを説明できなかった。これは、CDCA、DCAよりも親水性の官能基 を多く持つCA、TCAでは、疎水的相互作用が弱く、6変数以外の他のパラメータの関与が大きい ためであると考えられる。
\end{abstract}

キーワード: 胆汁酸、アミノ酸、ミセル動電クロマトグラフィー、GA-PLS、疎水的相互作用

\footnotetext{
*kenji@sparklx.chem.yamaguchi-u.ac.jp
} 


\section{2．実験方法および計算方法}

\section{1. 緒言}

キャピラリー電気泳動(Capillary Electrophoresis、 CE)は、高速、高分離、測定に必要なサンプル量が 少ない等の特徵を有していることから、近年著しい 発展を遂げた分析方法で、DNA解析や光学異性体分 離の分野においては主要な分析法として確立されつ つある。CEにはその分離原理により種々の分離モー ドが存在し、その分離モードの一つであるミセル動 電クロマトグラフィー (Micellar Electrokinetic Chromatography、MEKC)はTerabeらによって報告さ れた分離分析方法である[1]。この方法は、移動相で ある泳動液に臨界ミセル濃度 $(\mathrm{CMC})$ 以上の界面活性 剂を添加し、泳動液中にミセルを生成させることで 擬似固定相を形成し、ミセルと測定試料との相互作 用の違いに基づき試料を分離する方法である。その ため、電荷を持たない中性分子や光学異性体の分離 を行うことができるため、有機化合物の分離に主に 用いられている。MEKCによる光学異性体の分離は、 これまで様々な研究例が報告されている[2,3]。その 光学異性体分離機構には疎水的相互作用が関与して いると考えられているが、分離機構に関与している 因子の統計的手法を用いた解析はいままで行われて いない。

本研究では、界面活性剂として4種類の胆汁酸類 (Fig.1)を用いて、MEKCによる11種類のアミノ酸の 光学異性体分離を行い、得られた結果から

$$
R s=\frac{2\left(t_{2}-t_{1}\right)}{\left(w_{2}+w_{1}\right)}
$$

$$
\left(\begin{array}{ll}
t_{1}: \text { ピーク } 1 \text { の泳動時間 } & t_{2}: \text { ピーク } 2 \text { の泳動時間 } \\
w_{1}: \text { ピーク } 1 \text { のピーク幅 } & w_{2}: \text { ピーク } 2 \text { のピーク幅 }
\end{array}\right)
$$

(1)式を用いて分離能を表す值の1つである分離度 (Rs)を算出した。算出されたRsを目的変数とし、ア ミ八酸の物性值や実験条件を説明変数とする GA-PLS法[4]による解析を行い、この解析により、 Rsに影響を与えるパラメータを明らかにすること を目的とした。

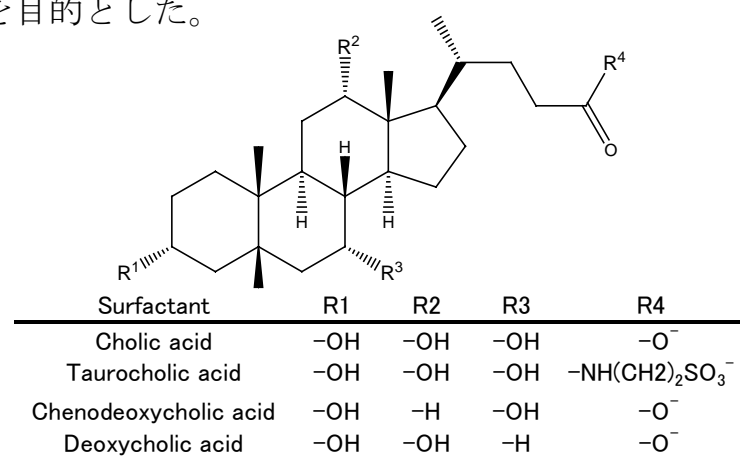

Fig. 1 Molecular structure of bile acid derivatives used for the Rs measurements.
測定には、キャピラリー電気泳動装置(Agilent Technologies製)、スタンダードフューズドシリカキ ヤピラリー(内径 $50 \mu \mathrm{m}$ 、全長 $48.5 \mathrm{~cm}$ 、有効長 $40 \mathrm{~cm}$ 、 Agilent Technologies製)、ソフトウェアは3D-CE Chem StationRevA,08.01(Agilent Technologies製)を用いた。 実験開始前にキャピラリーに対する前処理として、 $0.1 \mathrm{MNaOH} 2$ 分間、蒸留水 15 分間、泳動液 10 分間 キャピラリー内部の洗浄を行った。試料注入は、 0.01

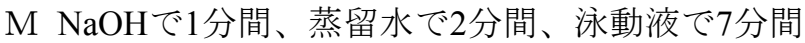
注入してキャピラリー内部の洗浄を行った後、試料 を加圧法 $(50 \mathrm{mbar} 、 5 \mathrm{sec})$ で注入し、次に泳動液を注 入 $(50 \mathrm{mbar} 、 5 \mathrm{sec}) し て$ 行った。印加電圧は入口側に $+15 \mathrm{kV}$ であり、測定温度 $20^{\circ} \mathrm{C}$ 、試料の測定は紫外吸 光光度計を用いて、測定波長 $334 \mathrm{~nm}$ で行った。

アミノ酸溶液はAla、Arg、Asn、Asp、Glu、Ile、 Lys、Val、Phe、Trp、TyrのL体およびD体をそれぞ れ5 mMアミノ酸水溶液に調製し、この溶液からそれ ぞれD-250 $\mu \mathrm{M} 、 \mathrm{~L}-500 \mu \mathrm{M}$ になるようにアミノ酸混 合溶液を調整した。アミノ酸誘導体化の溶液は、ア セトニトリル $1 \mathrm{ml}$ にo-フタルアルデヒド(OPA) $8 \mathrm{mg}$ $(0.06 \mathrm{M})$ と2,3,4,6-テトラ-O-アセチル-1-チオ- $\beta$-Dグルコピラノース(TATG) $44 \mathrm{mg}(0.12 \mathrm{M})$ を溶解さ せ、OPA/TATG溶液を調整した。アミノ酸混合溶液750 $\mu$ ににホウ酸緩衝液 $(\mathrm{pH}=9.5) 150 \mu 1$ 、OPA/TATG溶液 $150 \mu 1$ 1を加えて攪拌し、室温で6分間静置することで アミノ酸の誘導体化を行った(Scheme 1)。

MEKCの泳動液には、 $60 \mathrm{mM}$ 胆汁酸(コール酸ナト リウム、ケノデオキシコール酸ナトリウム、デオキ シコール酸ナトリウム、デヒドロコール酸ナトリウ ム、タウロコール酸ナトリウム) と $4 \mathrm{vol} \%$ アセトリト リルを含むリン酸緩衝液 $(\mathrm{pH}=8.0, \mu=50 \mathrm{mM})$ を用 いた。

多変量解析には、船津らにより開発された Chemish version3.03[5]を用いた。

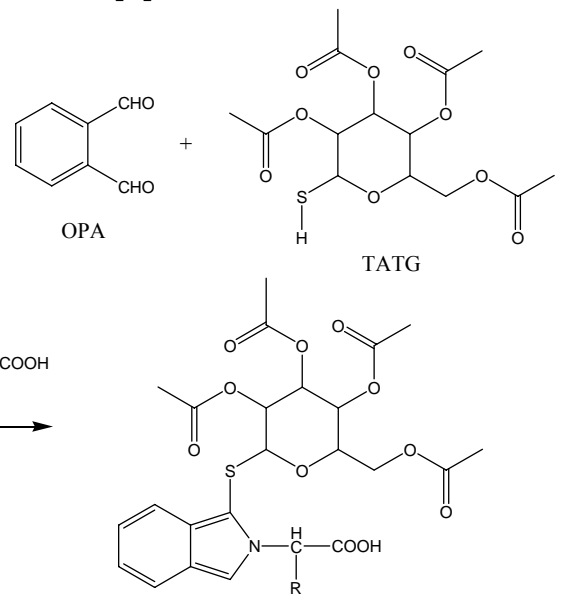

Scheme1 Derivatization of amino acid with OPA/TATG. 


\section{GA-PLSの設定を以下に示す。}

・ 遺伝的アルゴリズム $(\mathrm{GA})$ の設定

世代数 : 1000 , 染色体数 : 30 ,

カットオフ率 : 30 , 生存率 : 30 ,

交差対数 : 5 , 突然変異率 : 1

\section{- PLS の設定}

センタリング：有，スケーリング : 有

クロスバリデーション: 有

\section{3. 結果と考察}

\section{1 アミノ酸の疎水性度(Hydropathy Index: Hi) とRsの関係}

測定例として、コール酸 $(\mathrm{CA})$ を用いたMEKCによ るAlaの光学異性体分離結果をFig.2に示す。また、測 定された泳動時間 $(\mathrm{t}=7.25 \sim 14.82 \mathrm{~min})$ 、測定ピーク 幅(平均值0.12 min)から算出したRs之今回の解析に 用いた全てのパラメータをTable 1にまとめた。

MEKCにおいては、ミセルとアミノ酸の疎水的相 互作用が影響していることが一般的に広く認知され ている。このことから、4種類の胆汁酸MEKCによる アミノ酸光学異性体分離に影響を与えるパラメータ について検討するため、Hi[6]とRsの相関を試みた (Fig.3)。CA、タウロコール酸(TCA)、ケノデオキシ コール酸(CDCA)、デオキシコール酸(DCA)において、 それぞれ $\mathrm{R}^{2}=0.493 、 0.489 、 0.645 、 0.6790$ 弱い相関 が認められたが、この結果はHiだけでは分離機構を 完全には説明することができないこと示している。 MEKCによる分離機構を説明するためにはHi以外の パラメータの影響を考慮する必要があると考えられ る。

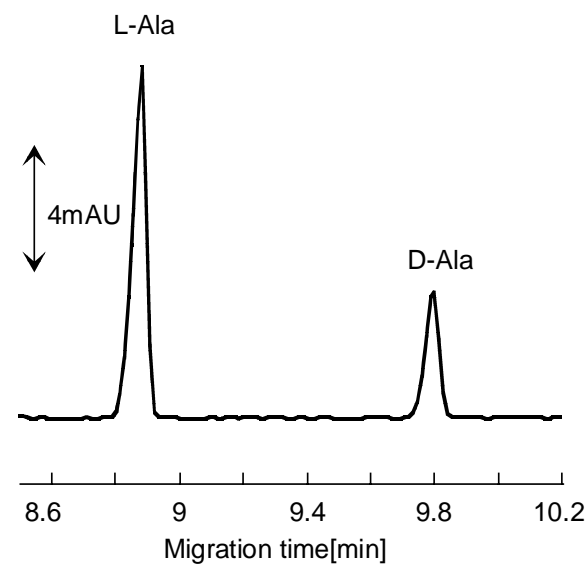

Fig.2 Sepration of L,D-Ala by MEKC using sodium cholate.

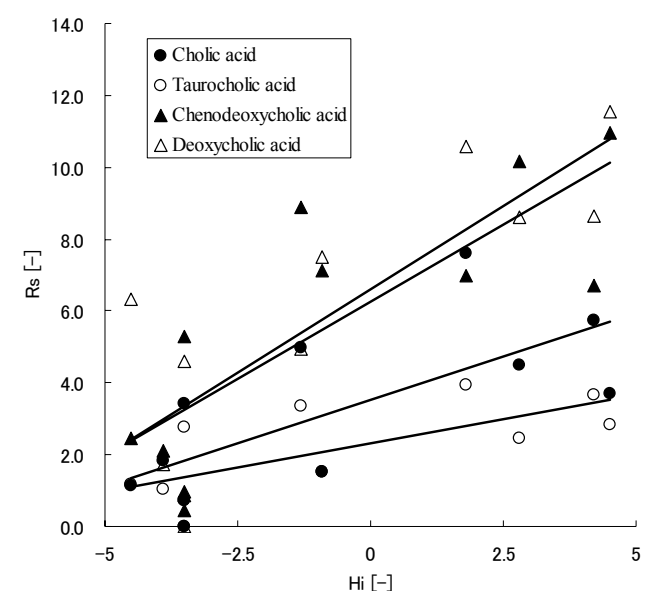

Fig.3 Hi vs. Rs plot for bile acids.

Table1 Experimental values and physical properties used for GA-PLS analysis.

\begin{tabular}{|c|c|c|c|c|c|c|c|c|}
\hline Surfactant & Amino acid & $\begin{array}{c}t_{B} \\
{[\mathrm{~min}]}\end{array}$ & $\begin{array}{c}\Delta \mathrm{L} \\
{[\mathrm{min}]}\end{array}$ & $\begin{array}{c}\Delta \mathrm{D} \\
{[\mathrm{min}]}\end{array}$ & $\begin{array}{l}\mathrm{Hi} \\
{[-]}\end{array}$ & $\begin{array}{l}\mathrm{pI} \\
{[-]}\end{array}$ & $\begin{array}{c}\mathrm{Mv} \\
{\left[\AA^{3}\right]}\end{array}$ & $\begin{array}{l}\text { Rs } \\
{[-]}\end{array}$ \\
\hline \multirow{10}{*}{ Cholic acid } & Ala & 5.20 & 4.10 & 4.79 & 1.8 & 6.00 & 100.6 & 7.59 \\
\hline & $\mathrm{Arg}$ & 3.89 & 4.14 & 4.30 & -4.5 & 10.76 & 185.1 & 1.16 \\
\hline & Asn & 5.16 & 3.13 & 3.32 & -3.5 & 5.41 & 129.5 & 3.41 \\
\hline & Asp & 6.73 & 5.60 & 5.60 & -3.5 & 2.77 & 123.0 & 0.00 \\
\hline & Glu & 6.67 & 4.78 & 4.85 & -3.5 & 3.22 & 150.1 & 0.72 \\
\hline & Ile & 4.86 & 9.05 & 9.96 & 4.5 & 6.02 & 178.5 & 3.68 \\
\hline & Lys & 4.65 & 8.47 & 8.17 & -3.9 & 9.74 & 180.1 & 1.84 \\
\hline & Phe & 5.02 & 5.42 & 5.86 & 2.8 & 5.48 & 201.4 & 4.49 \\
\hline & Trp & 5.13 & 4.19 & 4.30 & -0.9 & 5.89 & 239.2 & 1.51 \\
\hline & Tyr & 5.18 & 3.93 & 4.33 & -1.3 & 5.66 & 205.2 & 4.98 \\
\hline \multirow{6}{*}{$\cdot--------$} & - - Val & & & -5.69 & $-\frac{4.2}{10}-$ & -5.96 & -151.6 & -5.73 \\
\hline & Ala & $\overline{5} .2 \overline{0}$ & $\overline{4} . \overline{9} 2$ & $5.4 \overline{9}$ & $\overline{1.8}-$ & $\overline{6} .00$ & $\overline{100} \overline{6}$ & $3 . \overline{9} 4^{-}$ \\
\hline & Arg & 3.89 & 5.26 & 5.43 & -4.5 & 10.76 & 185.1 & 1.18 \\
\hline & Asn & 5.16 & 4.02 & 4.27 & -3.5 & 5.41 & 129.5 & 2.77 \\
\hline & Asp & 6.73 & 5.11 & 5.11 & -3.5 & 2.77 & 123.0 & 0.00 \\
\hline & Glu & 6.67 & 7.73 & 7.85 & -3.5 & 3.22 & 150.1 & 0.72 \\
\hline \multirow[t]{5}{*}{ Taurocholic acid } & Ile & 4.86 & 6.63 & 7.01 & 4.5 & 6.02 & 178.5 & 2.84 \\
\hline & Lys & 4.65 & 9.12 & 8.84 & -3.9 & 9.74 & 180.1 & 1.02 \\
\hline & Phe & 5.02 & 6.66 & 7.07 & 2.8 & 5.48 & 201.4 & 2.44 \\
\hline & Trp & 5.13 & 4.19 & 4.30 & -0.9 & 5.89 & 239.2 & 1.51 \\
\hline & Tyr & 5.18 & 6.04 & 6.46 & -1.3 & 5.66 & 205.2 & 3.35 \\
\hline \multirow[t]{5}{*}{$\cdot--------$} & $--\frac{V a l}{A} l^{a}$ & $-\frac{5.34}{5.20}$ & $\frac{5}{2} \cdot \frac{61}{30}$ & $-\frac{6.03}{29}$ & $-\frac{4.2}{1.8}-$ & -5.96 & -151.6 & -3.66 \\
\hline & Arg & 3.89 & 5.09 & 5.42 & $\begin{array}{l}1.0 \\
-4.5\end{array}$ & $\begin{array}{l}0.00 \\
10.76\end{array}$ & 185.1 & 2.46 \\
\hline & Asn & 5.16 & 2.09 & 2.55 & -3.5 & 5.41 & 129.5 & 5.29 \\
\hline & Asp & 6.73 & 1.78 & 1.84 & -3.5 & 2.77 & 123.0 & 0.43 \\
\hline & Glu & 6.67 & 1.44 & 1.53 & -3.5 & 3.22 & 150.1 & 0.97 \\
\hline \multirow[t]{11}{*}{ Chenodeoxycholic acid } & Ile & 4.86 & 6.70 & 7.88 & 4.5 & 6.02 & 178.5 & 10.95 \\
\hline & Lys & 4.65 & 6.86 & 6.65 & -3.9 & 9.74 & 180.1 & 2.11 \\
\hline & Phe & 5.02 & 6.95 & 8.55 & 2.8 & 5.48 & 201.4 & 10.15 \\
\hline & Trp & 5.13 & 3.02 & 3.67 & -0.9 & 5.89 & 239.2 & 7.12 \\
\hline & Tyr & 5.18 & 4.04 & 5.18 & -1.3 & 5.66 & 205.2 & 8.89 \\
\hline & Val & $-\frac{5}{5} 34$ & 2.74 & -3.39 & -4.2 & -5.96 & -151.6 & -6.70 \\
\hline & Al & 5.20 & 3.68 & 4.60 & 1.8 & 6.00 & 100.6 & 10.58 \\
\hline & $\operatorname{Arg}$ & 3.89 & 5.54 & 6.23 & -4.5 & 10.76 & 185.1 & 6.32 \\
\hline & Asn & 5.16 & 2.94 & 3.35 & -3.5 & 5.41 & 129.5 & 4.59 \\
\hline & Asp & 6.73 & 3.27 & 3.27 & -3.5 & 2.77 & 123.0 & 0.00 \\
\hline & Glu & 6.67 & 3.19 & 3.29 & -3.5 & 3.22 & 150.1 & 0.87 \\
\hline \multirow[t]{6}{*}{ Deoxycholic acid } & Ile & 4.86 & 5.40 & 6.37 & 4.5 & 6.02 & 178.5 & 11.56 \\
\hline & Lys & 4.65 & 8.74 & 8.53 & -3.9 & 9.74 & 180.1 & 1.74 \\
\hline & Phe & 5.02 & 4.35 & 5.20 & 2.8 & 5.48 & 201.4 & 8.59 \\
\hline & Trp & 5.13 & 4.60 & 5.27 & -0.9 & 5.89 & 239.2 & 7.50 \\
\hline & Tyr & 5.18 & 3.40 & 3.76 & -1.3 & 5.66 & 205.2 & 4.95 \\
\hline & Val & 5.34 & 4.18 & 5.06 & 4.2 & 5.96 & 151.6 & 8.64 \\
\hline
\end{tabular}

Table2 Results of GA-PLS analysis for observed Rs's.

\begin{tabular}{|c|c|c|c|c|c|}
\hline Structure & No. & parameters & $Q^{2}$ & $\mathrm{R}^{2}$ & $\begin{array}{c}\text { optimal number of } \\
\text { components }\end{array}$ \\
\hline Cholic acid & 1 & $\Delta \mathrm{L}, \mathrm{Hi}$ & 0.425 & 0.576 & 1 \\
\hline$-\overline{\text { Taurochoolic acid }}$ & & $-\frac{\mathrm{Hi}}{\Delta \mathrm{L},},-\mathrm{Hi}$ & $\begin{array}{l}0.260 \\
0.326\end{array}$ & $\begin{aligned} & 0.492 \\
& 0.540\end{aligned}$ & $\frac{1}{1}-$ \\
\hline 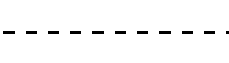 & & $-\overline{\mathrm{Hi}}, \overline{\mathrm{pl}} \overline{\mathrm{pl}}, \overline{\mathrm{Mv}}-$ & $\begin{array}{l}0.283 \\
0.827\end{array}$ & $\begin{array}{r}0.489 \\
-0.948\end{array}$ & $\frac{1}{4}----$ \\
\hline \multirow{2}{*}{ Chenodeoxycholic acid } & 2 & $t_{B}, H i, p I$ & 0.775 & 0.924 & 3 \\
\hline & 3 & $\Delta \mathrm{D}, \mathrm{Hi}$ & 0.582 & 0.715 & 1 \\
\hline & & $-\overline{\mathrm{L}}, \overline{\mathrm{Hi}}, \bar{\Delta} \overline{\mathrm{D}}, \overline{\mathrm{Hi}}$ & 0.473 & -0.645 & $\frac{1}{3}$ \\
\hline \multirow{3}{*}{ Deoxycholic acid } & 2 & $\mathrm{t}_{\mathrm{B}}, \Delta \mathrm{L}, \mathrm{Hi}$ & 0.808 & 0.923 & 3 \\
\hline & 3 & $t_{B}, H i$ & 0.793 & 0.867 & 1 \\
\hline & 4 & $\mathrm{Hi}$ & 0.515 & 0.649 & 1 \\
\hline
\end{tabular}




\section{2 GA-PLS法による解析}

目的変数を $\mathrm{Rs} 、$ 説明変数に $\mathrm{t}_{\mathrm{B}} 、 \Delta \mathrm{L} 、 \Delta \mathrm{D} 、 \mathrm{Hi} 、 ア ミ$ ノ酸の等電点 $(\mathrm{pI})[7] 、 ア ミ ノ$ 酸の分子体積 $(\mathrm{Mv})[8]$ の6 変数を用い、Chemish 3.03を用いてGA-PLS法による 解析を行った。 $\mathrm{t}_{\mathrm{B}}$ は泳動液にリン酸緩衝液を用いて CEを行ったときのアミノ酸の泳動時間、 $\triangle \mathrm{L}$ はMEKC を行ったときのL体の泳動時間 $\left(\mathrm{t}_{\mathrm{L}}\right)$ と $\mathrm{t}_{\mathrm{B}}$ との差、 $\Delta \mathrm{D}$ は $\mathrm{D}$ 体の泳動時間 $\left(\mathrm{t}_{\mathrm{D}}\right)$ と $\mathrm{t}_{\mathrm{B}}$ との差である。4種類の胆汁酸 ミセルを用いたMEKCのGA-PLS法のよる解析結果 をTable2にまとめた。

\section{3．2．1 ケノデオキシコール酸(CDCA)}

GA-PLS法による解析結果より、GAの変数選択に

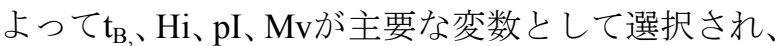
高い $\mathrm{Q}^{2}$ 值を持つ相関式が得られた $\left(\right.$ No. $1, \mathrm{Q}^{2}=0.827$, $\mathrm{R}^{2}=0.948$ ，最適成分数 4$)$ 。多変量解析において、多 重共線性がある(説明変数間に強い相関や一次従属 な変数関係がある)と相関式の信頼性が低下する。こ のことより、4変数間の多重共線性について検討する ために、多重共線性を検出するための指標の一つで あるVIF值(Variance Inflation Factor)を(2)式を用いて 算出した[9]。(2)式における $\mathrm{R}_{\mathrm{j}}{ }^{2}$ は説明変数 $\mathrm{j}$ 目的変 数とし、残りの説明変数を説明変数とした重回帰分 析の決定係数である。

$$
V I F_{j}=\frac{1}{1-R_{j}^{2}}
$$

4変数のVIF值を算出した結果、全ての変数の $\mathrm{VIF}<10$ であった。このことから、No.1の相関式はRs を記述する式として適当と考えられる。この相関式 から得られた $\mathrm{Rs}_{\mathrm{obs}}-\mathrm{Rs}_{\mathrm{calc}}$ プロットをFig.4に示す。この 式における標準回帰係数(b) は $\mathrm{t}_{\mathrm{B}}(-1.32)>\mathrm{pI}(-1.19)>\mathrm{Hi}($ $0.45)>\operatorname{Mv}(0.18)$ であり、この結果から疎水性よりも溶 質の移動度、電荷が分離機構に大きく関与している ことがわかった。

また、Arg、Lysの2点( $\bigcirc$ 内の值) は $\mathrm{Y}_{\mathrm{obs}}$ と $\mathrm{Y}_{\text {calc }}$ の值 の相関が弱かった。これは、この2つのアミノ酸が側 鎖に- $\mathrm{NH}_{3}{ }^{+}$を持っている、即ち正電荷を帯びている、 ことが原因であると考えられる。この結果もアミノ 酸の電荷が分離機構に大きく関与していることを裏 付けている。

\section{2． 2 デオキシコール酸(DCA)}

DCAの系におけるGA-PLS法による解析結果は、 $\mathrm{t}_{\mathrm{B}, ~}$ $\Delta \mathrm{L} 、 \Delta \mathrm{D} 、 \mathrm{Hi}$ 主要な変数として選択し、高い $\mathrm{Q}^{2}$ 值 を持つ相関式が得られた $\left(\right.$ No. $1, \mathrm{Q}^{2}=0.819, \mathrm{R}^{2}=0.923$, 最適成分数 3)。しかしながら、選択された4変数に
おけるVIF值を算出した結果、多重共線性が存在し た $\left(\mathrm{VIF}_{\Delta \mathrm{L}}=125.0 、 \mathrm{VIF}_{\Delta \mathrm{D}}=142.9\right) 。 こ の$ 結果は、No.1の 相関式がRsを記述する式として適当ではないこと

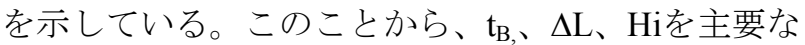
変数として選択した No.2 の相関式 $\left(\mathrm{R}^{2}=0.923\right.$, $\mathrm{Q}^{2}=0.808$, 最適成分数 3)について検討を行った。選 択された3変数のVIF值を算出した結果、全ての変数 のVIF<10であったことから、No.2の相関式がRsを記 述する式として適当と考えられる。No.2の相関式の $\mathrm{Rs}_{\mathrm{obs}}-\mathrm{Rs}_{\mathrm{calc}}$ プロットをFig.5に示す。この式における標 準回帰係数(b)は、 $\mathrm{Hi}(0.73)>\mathrm{t}_{\mathrm{B}}(-0.61)>\Delta \mathrm{L}(-0.29)$ であつ た。この結果から、DCAにおいては疎水性の影響が 一番大きく、次に溶質の移動度の関与が大きいと考 えられる。

CDCAの場合と異なり、主要な変数に電荷的性質 を表すパラメータである $\mathrm{pI}$ は選択されなかった。こ のことから、CDCAとDCAは類似な構造、物性を持 っているが、異なる分離機構を持っていることが推 察される。また、 $\Delta \mathrm{L}$ が変数に選択されたことから、 L体と胆汁酸ミセルの相互作用の違いがRsに影響し ていることが示唆された。

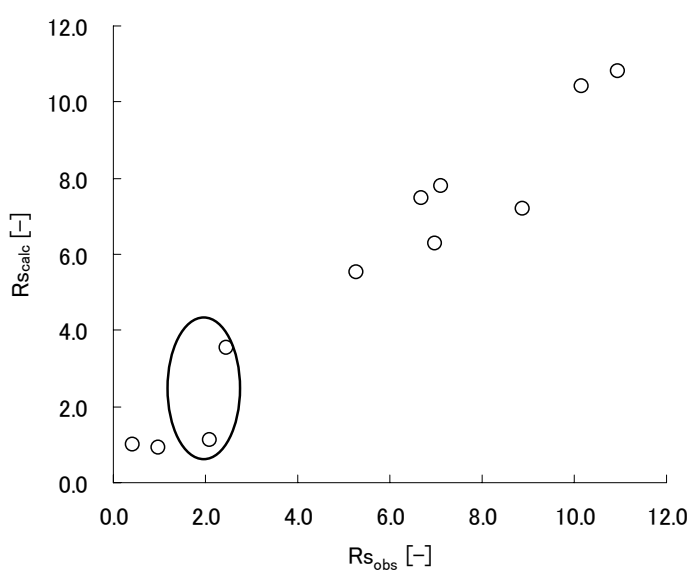

Fig.4 Rs $\mathrm{obs}-\mathrm{Rs}_{\mathrm{calc}}$ plot for CDCA.

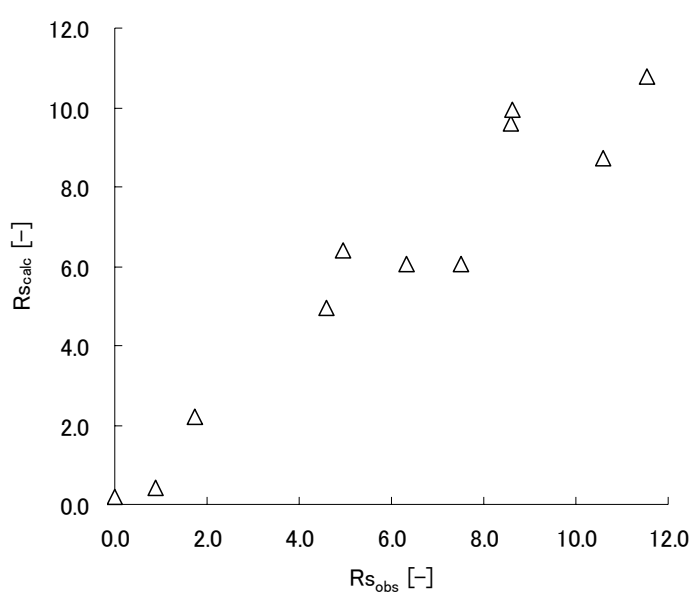

Fig.5 $\mathrm{Rs}_{\mathrm{obs}}-\mathrm{Rs}_{\text {calc }}$ plot for DCA. 


\section{3 . 2.3 他の胆汁酸(CA、TCA)}

CA、TCAの系においては、ともにGAの変数選択 によって $\Delta \mathrm{L} 、 H i か ゙$ 主要な変数として選択された。し かしながら、最も高い $\mathrm{Q}^{2}$ 值はそれぞれ $\mathrm{Q}^{2}=0.425$ 、 0.326であり、今回用いた6変数では良好なモデル化 を行うことができなかった。このことからCA、TCA の系においては実験值以外のパラメータ、例えば理 論計算等から得られる分子間相互作用エネルギー等 の值を考慮する必要があると考えられる

\section{4. 結論}

本研究では、GA-PLS法による解析を用いて胆汁 酸ミセルによるMEKCのアミノ酸光学異性体分離機 構に影響を与えるパラメータの検討を行った。全て の系において、GAの変数選択により Hiが選択され、 アミノ酸の疎水的相互作用が関与していることが統 計的に証明されたといえる。CDCA、DCAの系にお いては、 $\mathrm{t}_{\mathrm{B}} 、 \Delta \mathrm{L} 、 \Delta \mathrm{D} 、 \mathrm{Hi} 、 \mathrm{pI} 、 \mathrm{Mv}$ の6変数から選択 された4または3変数を用いることでモデル化を行う ことができたが、CA、TCAの系においてはこの6変 数のみではそれらのRsを説明できなかった。これは、 CA、TCAがCDCA、DCAよりも親水性の官能基を多 く持つため、疎水的相互作用が弱く、6変数以外の他 のパラメータの関与が大きいためであると考えられ る。全ての系のモデル化を可能にするパラメータに ついて検討するために、我々は現在、理論計算から 得られる分子間相互作用エネルギーなどのパラメー タを用いることを検討している。

\section{5 . 参考文献}

[1] S. Terabe, K. Otsuka, K. Ichikawa, A. Tsuchiya, Anal. Chem., 56 , 111-113 (1984).

[2] K. Tian, H. Chen, J. Tang, X. Chen, Z. Hu, Journal of Chromatography A, 1132, 333-336(2006).

[3] Z. Wang, Z. Tang, Z. Gu, Z. Hu, Electrophoresis, 26, 1001-1006(2005).

[4] K. Hasegawa, Y. Miyashita, K. Funatsu, J. Chem. Inf. Comput. Sci., 37, 306-310(1997).

[5] Chemish ver.3.03, ChemInfoNavi Home Page (URL=http://www.cheminfonavi.co.jp/index.html)

[6] J. Kyte and R. F. Doolittle, J. Mol. Biol., 157, 105-132(1982).

[7] 日本化学会編, 化学便覧 基礎編改訂 5 版, 丸 善, 611-614(2004).

[8] A.A. Zamyatin, Prog. Biophys. Mol. Biol., 24, 107-123(1972).

[9] 田中豊, 垂水共之, 脇本和昌 編, パソコン統計 解析ハンドブック 多変量解析編, 共立出版, 1992. 


\title{
A Chemoinformatics Approach for Enantioseparation Mechanism of Amino Acids by Micellar Electrokinetic Chromatography Using Bile Acids
}

\author{
Yutaka Ikenaga ${ }^{\mathrm{a}}$, Misa Hanaki ${ }^{\mathrm{a}}$, Michinori Sumimoto ${ }^{\mathrm{a}}$, Hiroshi Shigi ${ }^{\mathrm{b}}$, \\ Tsutomu Nagaoka ${ }^{b}$, and Kenzi Hori ${ }^{\mathrm{a}^{*}}$ \\ ${ }^{a}$ Graduate School of Science and Engineering, Yamaguchi University, 2-16-1 Tokiwadai, \\ Ube 755-8611, Japan, ${ }^{b}$ Research Institute of Advanced Science and Technology, Osaka \\ Prefecture University, 1-2 Gakuencho, Sakai 599-8570, Japan
}

\begin{abstract}
Micellar electrokinetic chromatography(MEKC) is one of the separation modes of capillary electrophoresis(CE) with high resolution. MEKC is useful for enantioseparations of organic compounds within a short analysis time even though sample volumes are very low. It has been considered that the hydrophobic interaction between solute and micelles is very important for enantioseparation of compounds. However, it has not been clearly understood what parameters are closely related to the separation mechanism of the MEKC. In the present study, The GA-PLS method was applied to find important parameters for the enantioseparations of amino acids using the MEKC with bile acids. For that purpose, the technique was used to enantioseparate eleven amino acids. Four bile acids such as cholic acid(CA), taurocholic acid(TCA), chenodeoxycholic acid(CDCA) and deoxycholic acid(DA) were adopted to make micellars interacting with the amino acids. The resolution values were calculated from the experimental results. The value is an index for the ability of the MEKC to enantioseparate the amino acids. Experimental values and physical properties such as hydropathy index of amino acids and isoelectric points of amino acids were used as explanatory variables for the statistical method. It was confirmed that three or four variables are enough to expect the experimental Rs values for CDCA and DCA while it is impossible to explain those for CA and TCA. It was considered that the difference of the hydrophilic property of the bile acids is the key to understanding the enantioseparations observed.
\end{abstract}

Keywords: bile acid, amino acid, micellar electrokinetic chromatography, GA-PLS, hydrophobic interaction

\footnotetext{
*kenji@sparklx.chem.yamaguchi-u.ac.jp
} 